\title{
Geological built and potential CCS perspectives in northern Poland
}

\author{
Klaudia Kusek* \\ Institute of Meteorology and Water Management - National Research Institute; Poland
}

Received: 7 October 2020

Accepted: 20 January 2021

Published online: 30 May 2021

\begin{abstract}
The world has been struggling with global warming for many years. One way to reduce this phenomenon is to limit anthropogenic carbon dioxide emission to the atmosphere, which is partly responsible for contemporary climate change. This problem is international, but each country is obliged to follow general recommendations. In Poland, the idea of underground carbon sequestration (CCS) is increasingly being considered in the last decade. Northern Poland seems to be one of the perspective areas. For this reason, the following article describes the possibility of underground $\mathrm{CO}_{2}$ injection in this area. It contains the detailed description of the geological structure of Northern Poland. Types of underground structures for sequestration were also selected. The article also describes the technical conditions for the $\mathrm{CO}_{2}$ injection process. The most numerous group of boreholes suitable for CCS are those with documented oil or gas deposits. They are usually Upper Permian, and less often Middle Cambrian or Silurian hydrocarbon geological traps, where $\mathrm{CO}_{2}$ can be used in the enhanced oil and gas recovery. There are also several boreholes with saline aquifers.
\end{abstract}

Keywords: carbon capture and storage; oil and gas in Poland, geology of northern Poland

\section{Introduction}

Over the last few decades we observe a close connection between increasing carbon dioxide in the atmosphere and human activity, especially in highly developed countries. It is estimated that $\mathrm{CO}_{2}$ concentration has increased by more than $85 \mathrm{ppm}$ in the last over 150 years (Tarkowski 2005). At the same time, we record an impact of this gas on climate change on the Earth. It is mainly related to the rise in average air temperature and ocean level. There is therefore a need to limit the supply of carbon dioxide to the atmosphere.

As a result, we invent technological solutions that will not only reduce $\mathrm{CO}_{2}$ emission, but also allow for its sustainable disposal (Irlam 2017). One of such approach seems to be carbon capture and storage (CCS) under the land surface, which involves capturing, transporting and injecting carbon dioxide into the deep, impermeable geological structures to limit the impact of this gas on the terrestrial and marine ecosystems (Loseth 2019).

\footnotetext{
${ }^{*}$ Corresponding author: Klaudia Kusek e-mail: klaudia.kusek@imgw.pl
} 
Such method allows us to use geological capture and storage by $\mathrm{CO}_{2}$ injection into deep saline aquifers, depleted coal and hydrocarbon deposits or currently used areas oil and gas extraction. Nevertheless, it is important to define the porosity, fracturing, as well as the presence of caverns and tectonic dislocations in such geological trap (Gaurina-Međimurec and Mavar 2019).

After reaching a historic increase in $\mathrm{CO}_{2}$ concentration (400 ppm) in May 2013, the United Nations Framework Convention on Climate Change (UNFCCC) called for responsibility to reduce its concentration. Poland is one of the countries, which committed to reduce $\mathrm{CO}_{2}$ emission to the atmosphere. Therefore, the aim of the article is to describe the geological traps in northern Poland that can be used in CCS process. There will be determined such features of their construction that will allow for continuous and safe injection and storage of carbon dioxide.

\section{Observational material and scope of study}

The article presents technical conditions to be met by geological traps in which carbon dioxide sequestration is carried out. Then, an attempt was made to find regions in the study area where the CCS process can take place.

The geological built of the area of northern Polish voivodships was characterized on the basis of data from reservoir wells shared by Central Geological Database of Polish Geological Institute National Research Institute. Due to the need for detailed consideration of the deep structures, the maps from Polish Geological Atlas (Nawrocki and Becker, 2017) were also used. There are no depleted coal deposits in the described area. Due to this fact, the boreholes where the CCS process can be carried out were divided into two groups:

- deep saline aquifers;

- conventional and unconventional hydrocarbon reservoirs.

\section{Physical and technological requirements for CCS traps}

In order to ensure that carbon dioxide can be injected, the reservoir rock should have adequate permeability values, but also be limited to the sealing layer. In order to understand the lateral variation within the trap, the reservoir rocks should be thoroughly examined for tightness of the sedimentary basin in which they are located. This gives us information on the causes of lithological differences in the geological structure used to store $\mathrm{CO}_{2}$, which allows us to understand the processes of fluid migration during their injection (Lee et al. 2020). Due to the specificity of $\mathrm{CO}_{2}$ injection processes, geological traps situated at depths exceeding $800 \mathrm{~m}$ are qualified as safe locations (Reguera et al. 2013).

Combined with porosity and permeability, the pressure and temperature conditions in the tested location are an important criterion for selection and characterization of carbon dioxide storage sites. $\mathrm{CO}_{2}$ is a gas of which compression rate increases significantly near the critical point (at a pressure of about 7.39 bar and a temperature of about 304,25 K) (Fig. 1).

Rock salts, as well as shale rocks have a relatively high tensile strength of 20 to 180 bar, which means that they should not be damaged even during the large $\mathrm{CO}_{2}$ injection (Małkowski et al. 2019). Carbon dioxide can be used also in the process of enhanced oil or gas recovery. The efficiency of $\mathrm{CO}_{2}$ injection into geological traps, according to the methods described by Gorecki et al. (2009), is determined by the equation:

$$
\mathrm{G}_{\mathrm{CO} 2}=\mathrm{A} \cdot \mathrm{h} \cdot \varphi \cdot \rho_{\mathrm{CO} 2} \cdot \mathrm{E} \quad,
$$

where $\mathrm{G}_{\mathrm{CO} 2}$ is the mass of stored carbon dioxide, $A$ - the trap surface $\mathrm{h}$ - thickness of the reservoir layer, $\varphi$ - rock porosity, $\rho_{\mathrm{CO} 2}-\mathrm{CO}_{2}$ density within the trap, $\mathrm{E}-\mathrm{CO}_{2}$ storage coefficient. 


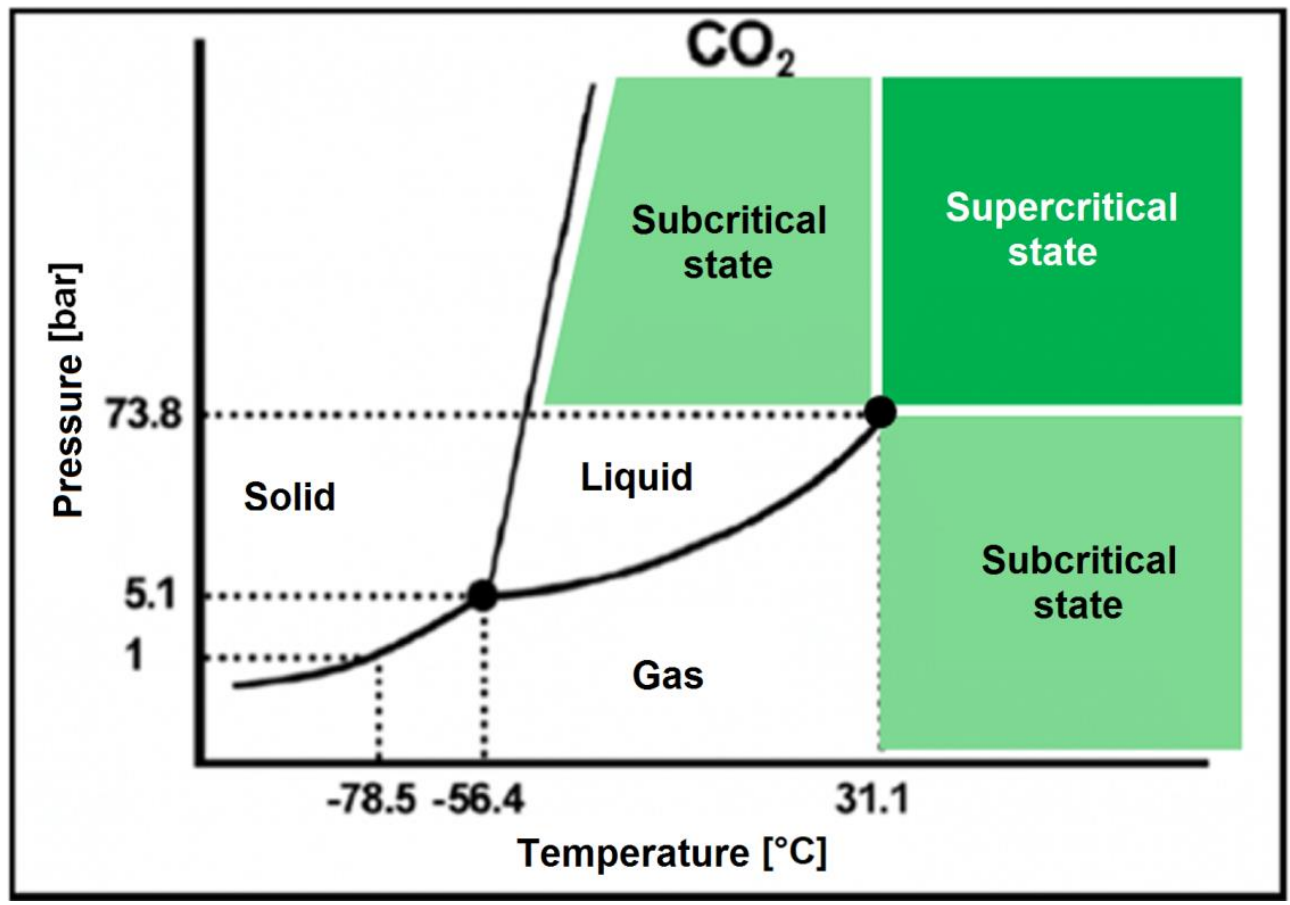

Fig. 1. States of $\mathrm{CO}_{2}$ aggregation and their thermodynamic conditions (based on: Müller et al. 2014).

\section{Location of the research area}

The research area covers three northern Polish voivodships: West Pomeranian, Pomeranian and Warmian-Masurian. There are 332 fully documented geological wells in this region that have been identified as potential reservoirs (Fig. 2). The overwhelming majority of them confirm the existence of crude oil and natural gas. There are more wells of this type in described location. They carry out continuous hydrocarbon exploitation (Kotarba et al. 2003; Więcław et al. 2010; Skupio and Barberes 2017).
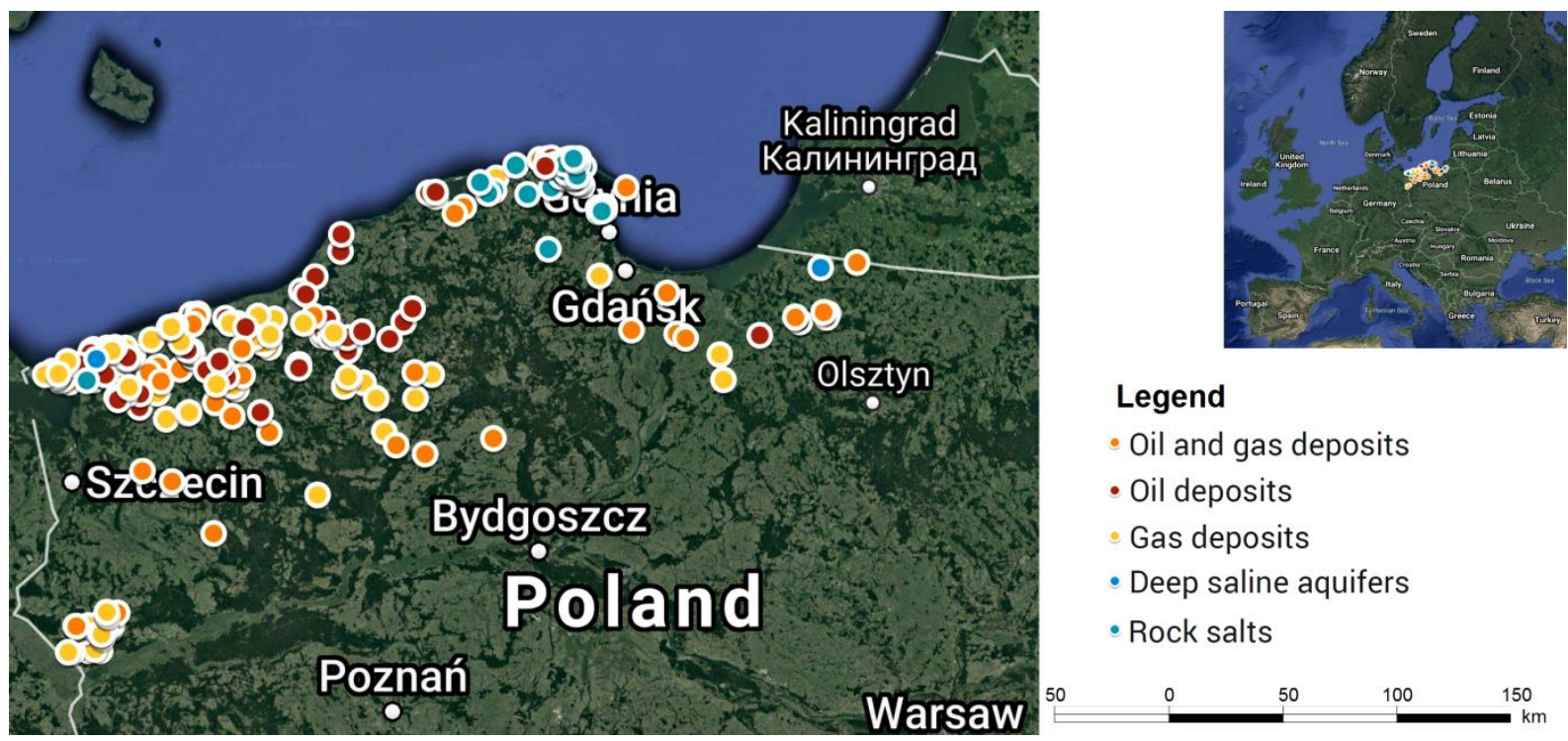

\section{Legend}

- Oil and gas deposits

- Oil deposits

- Gas deposits

- Deep saline aquifers

- Rock salts

Fig. 2. Location of described boreholes (source: Google Maps). 
Northern Poland is located in the area of two vast geological units: Precambrian East European Craton (EEC) in the eastern part and Western European Platform (Paleozoic Platform) in the west. The Trans-European Suture Zone (TESZ) is between them (Majorowicz 2004; Nawrocki and Poprawa 2006). There are minor earthquakes within this zone, though, not exceeding 4 on the Richter scale (Orlienok and Pęcherzewski 2007; Tatevossian et al. 2011). Two smaller subregions belong to the East European Craton in Northern Poland: elevation of Łeba and the Peribaltic Syneclise (Wawrzyniak-Guz 2019). Three geological units - Szczecin Synclinorium, Pomeranian Anticlinorium and Pomeranian Synclinorium are located within the Paleozoic Platform. The Lower and Upper Palaeozoic deposits in these areas are rich in mineral resources, mainly crude oil, natural gas and evaporates (JarmołowiczSzulc 1998). These types of structures are natural geological traps, ideally suited to carrying out the $\mathrm{CO}_{2}$ injection process (Solomon and Flach 2010; Salim et al. 2015; Verma 2015).

In the north-west of Poland, deep boreholes usually reach the Lower Permian formations. Potential structures that can be injected are at a depth of about 2000-3000 m (Peryt 1986; Peryt 2005; Maliński et al. 2009). In any case, they often do not have a significant number of caverns or crevices. These conditions are met mainly by the Barnówko-Mostno-Buszewo oil field, large area of which is located in the West Pomeranian Voivodeship (Mamczur et al. 1997; Tatarynowicz 2001).

The northern and north-eastern part of Poland is already in the area of the East European Platform, due to which boreholes often reach Cambrian or Precambrian formations.

For this reason, in the area of Northern Poland, structures enabling $\mathrm{CO}_{2}$ sequestration are also found in the Devonian, Silurian and Cambrian deposits. As in the north-west, most safe geological traps are associated with natural gas and oil resources.

Therefore, the described area has geological structures located at a depth of more than $800 \mathrm{~m}$, having appropriate parameters of porosity, fracture and cavity. They can be analysed as places intended for permanent, safe injection and storage of carbon dioxide (Eremin and Nazarova 2001). These are mainly deposits of evaporates, hydrocarbons and individual cases of deep saline aquifers.

\section{Results}

287 boreholes documenting geological traps located at a depth of over $800 \mathrm{~m}$ were found in the study area. The vast majority of them are associated with oil and gas deposits. Much less numerous group are deep saline aquifers (only 2 locations).

\section{Deep saline aquifers}

There are two locations in Northern Poland, where deep saline aquifers not found co-exist with hydrocarbon deposits. However, this does not exclude the possibility of $\mathrm{CO}_{2}$ injection processes. In both described places: Żelazna Góra (Fig. 3) and Kamień Pomorski, geological traps are Triassic deposits lying between Permian evaporates and Jurassic claystones. Such location suggests the possibility of performing the CCS process safely. In addition, during injection of $\mathrm{CO}_{2}$, halite precipitates from the brines, which also performs seal functions. An analogous process has been taking place for over 20 years in the Miocene Utsira field in Norway, located at a depth of about 800 to $100 \mathrm{~m}$ beneath seafloor (Akervoll et al. 2009; Furre et al. 2017; Kvamme and Aromada 2018). Similar structures in Poland are located on land, at a depth of $885 \mathrm{~m}$ (Żelazna Góra) and $991 \mathrm{~m}$ (Kamień Pomorski) respectively. However, the deposit in Żelazna Góra is only $12 \mathrm{~m}$ thick. The thickness of the saline water formation in Kamień Pomorski (about $150 \mathrm{~m}$ ) is similar to that from Utsira, but its lateral extent is definitely smaller (Gavenas et al. 2015). 
Klaudia Kusek

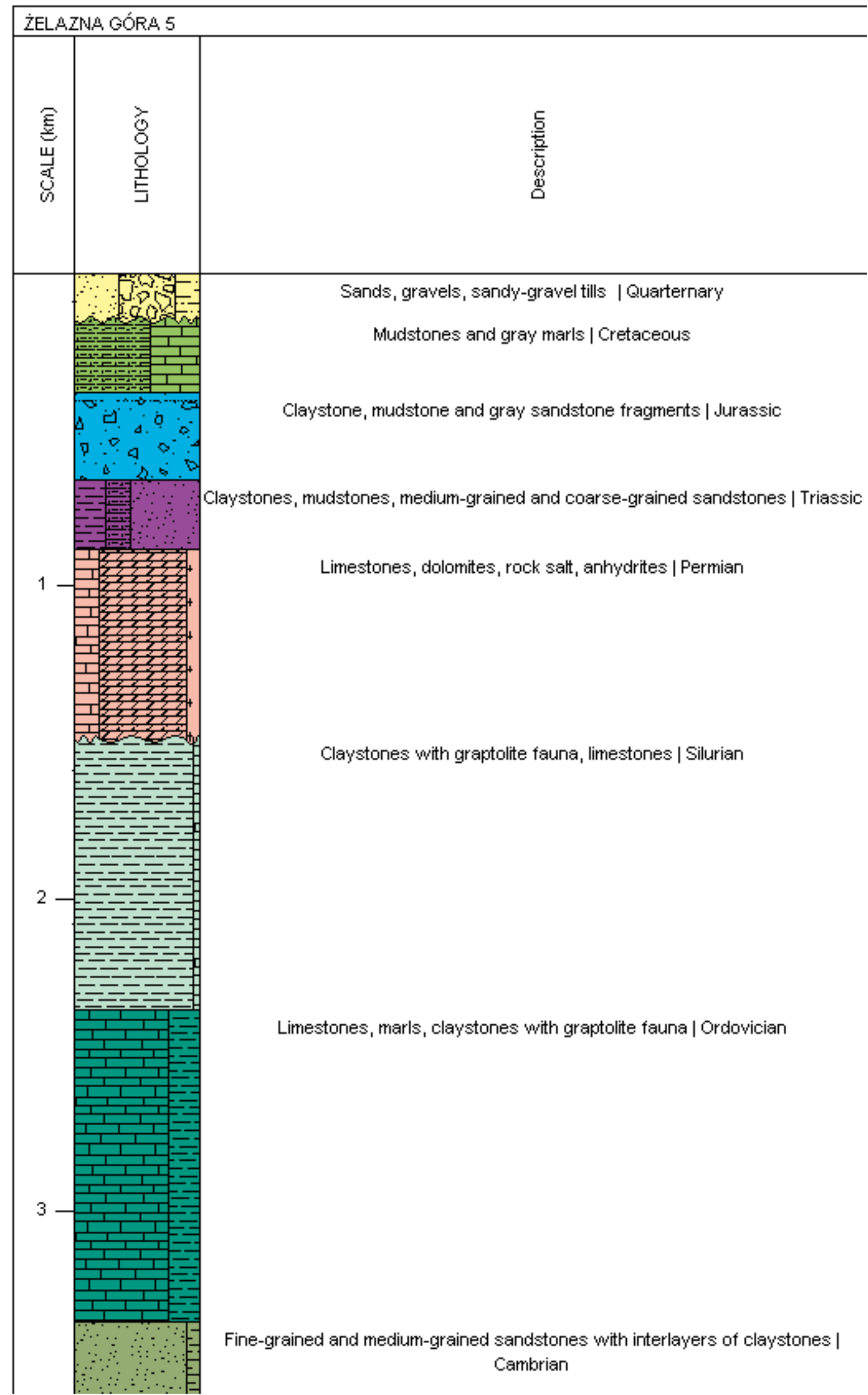

Fig. 3. Simplified profile of geological formations in Żelazna Góra (Warmian-Masurian Voivodeship) - chronostratigraphy and lithology. 


\section{Oil and gas deposits}

There are 291 boreholes in the study area where oil and gas deposits are likely to occur. The significant majority of potential reservoir traps occur here at the depths exceeding $1500 \mathrm{~m}$. Only 3 of them do not meet this condition. In fact, some holes have only traces of oil and gas, negligible thickness of the reservoir layers or no collector features. In 134 of them, however, hydrocarbons were found in layers of relatively high thickness (from several dozen to several hundred meters). Five have even documented several oil and gas traps from different geological periods. Oil and gas deposits in northern Poland are usually found in the Upper Permian formations (Fig. 4; Zych 2005; Czekański et al. 2010; Kosakowski and Krajewski 2015). In the north-eastern area, they are much more often found in Silurian and Ordovician graptolite shales or Middle Cambrian sandstones (Fig. 5; Więcław et al. 2010; Kotarba 2010; Kotarba and Lewan 2013). In the northwest, there are sporadic Upper Carboniferous and Upper Devonian deposits. In the northwest, there are also single Upper Carboniferous and Upper Devonian deposits. Substantially all of documented hydrocarbon deposits in the described area are still exploited. It is therefore possible to carry out not only the injection of carbon dioxide, but also enhanced oil and gas recovery (EOR/EGR) to increase reservoir pressure and extract hydrocarbons more efficiently.

In Northern Poland, there are mainly conventional deposits, where the $\mathrm{CO}_{2}$-EOR/EGR process can be carried out analogously to existing foreign enterprises (Carolus et al. 2017; Elmabrouk et al. 2017; ADB 2019). Some of them, however, are shale gas deposits (Jarzyna et al. 2017), where $\mathrm{CO}_{2}$ can be used for dry fracturing and later safely stored in such geological structures.

There are two groups of methods that use carbon dioxide in the hydraulic fracturing process (Labuda 2014). The first of them, currently often used in shale gas extraction in the USA, is based on the utilization of so-called energized fluids - ingredients preventing by receding of the space between clay particles in shale and with water and a small or large addition of carbon dioxide in the liquid state (Wang et al. 2020; Li et al. 2015; Zhang et al. 2019). The second, patented in 2013 (Middleton et al. 2014; Watts and Watts 2015), assumes the use of carbon dioxide itself, using the fact that, as it moves from liquid to gaseous $\mathrm{CO}_{2}$, it increases its volume and protects spaces in the shale rock before reducing them. Notwithstanding, carbon dioxide injection into shale formations is also considered for permanent storage, even if the hydrocarbon resources contained therein will be depleted.

\section{Estimating the volume of geological traps intended for $\mathrm{CO}_{2}$ injection}

Due to insufficient data, the deep saline aquifers were not further analyzed. However, an attempt was made to assess the suitability of hydrocarbon traps situated at a depth of more than $800 \mathrm{~m}$ (as recommended Reguera et al. 2013). It is defined for the conditions after depletion or during the gradual filling to the calculated capacity (Fig. 6).

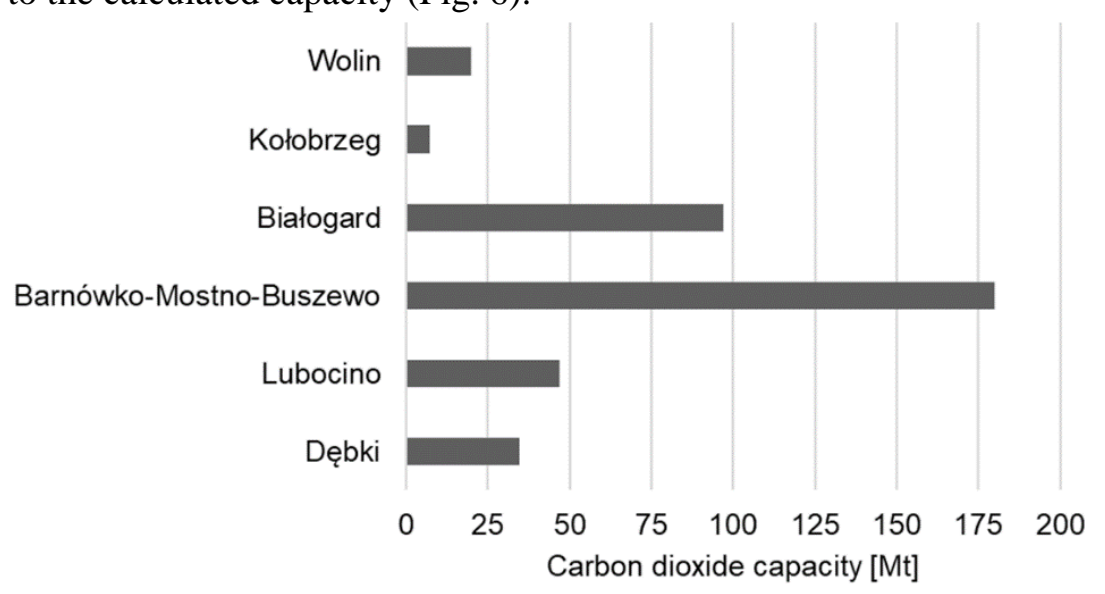

Fig. 6. Capacity of carbon dioxide underground storage in northern Poland geological traps (based on Eq. 1). 


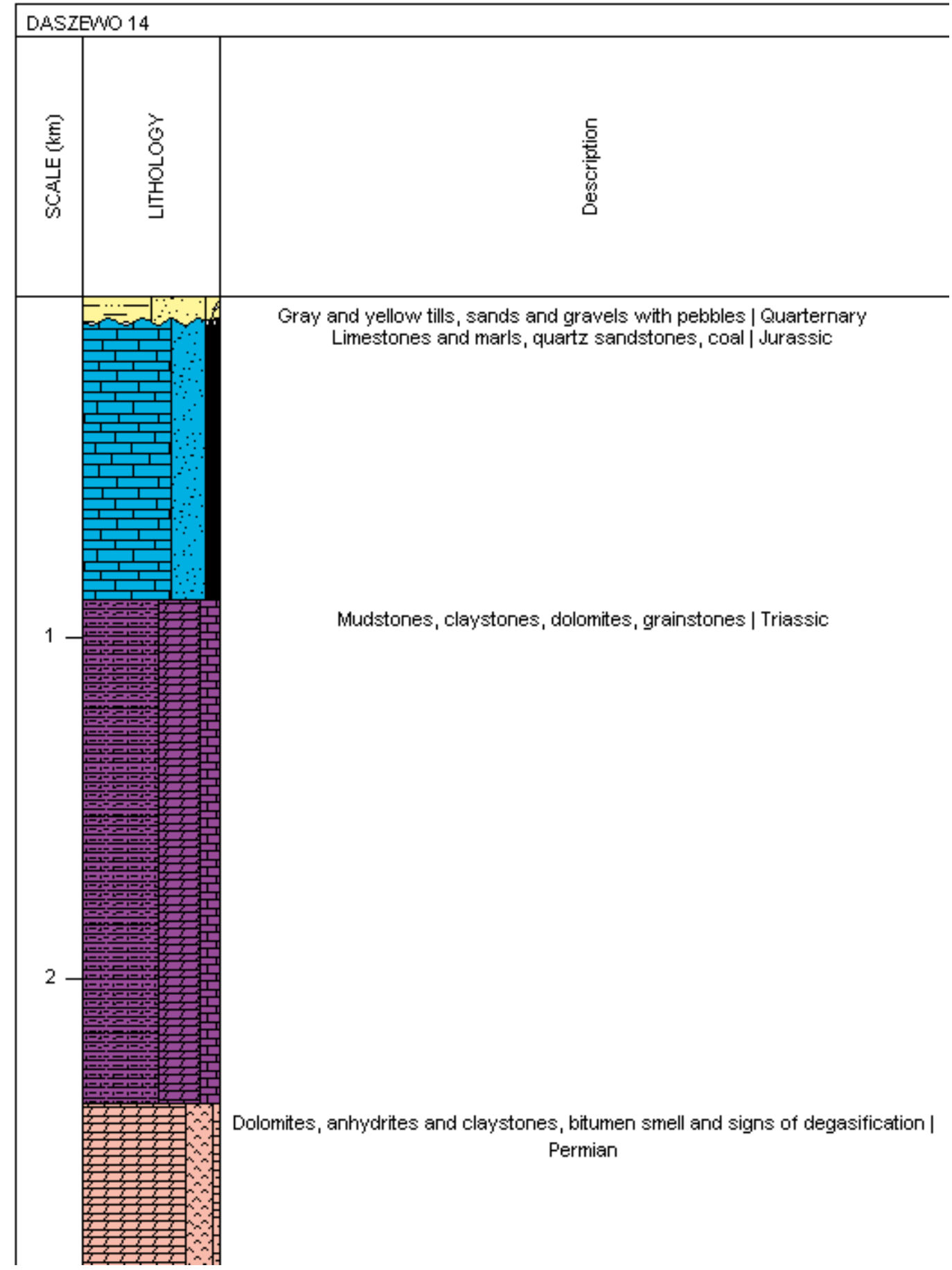

Fig. 4. Simplified profile of geological formations in Daszewo (West Pomeranian Voivodeship) chronostratigraphy and lithology.

The obtained results indicate relatively high potential for underground carbon dioxide storage. They are associated with the Lower and Upper Palaeozoic hydrocarbon deposits: Cambrian (Dębki), Ordovician / Silurian (graptolite shales, Lubocino) and Permian (Barnówko-Mostno-Buszewo, Białogard, Kołobrzeg, Wolin). The described oil and gas resources are still exploited. For this reason, some of their data is not publicly available. This may result in underestimating the thickness and area of these geological structures. Nevertheless, at this stage of research there is a great potential for their use in the CCS process. Barnówko-Mostno-Buszewo, considered to be the largest hydrocarbon field in Poland, is of particular importance. 


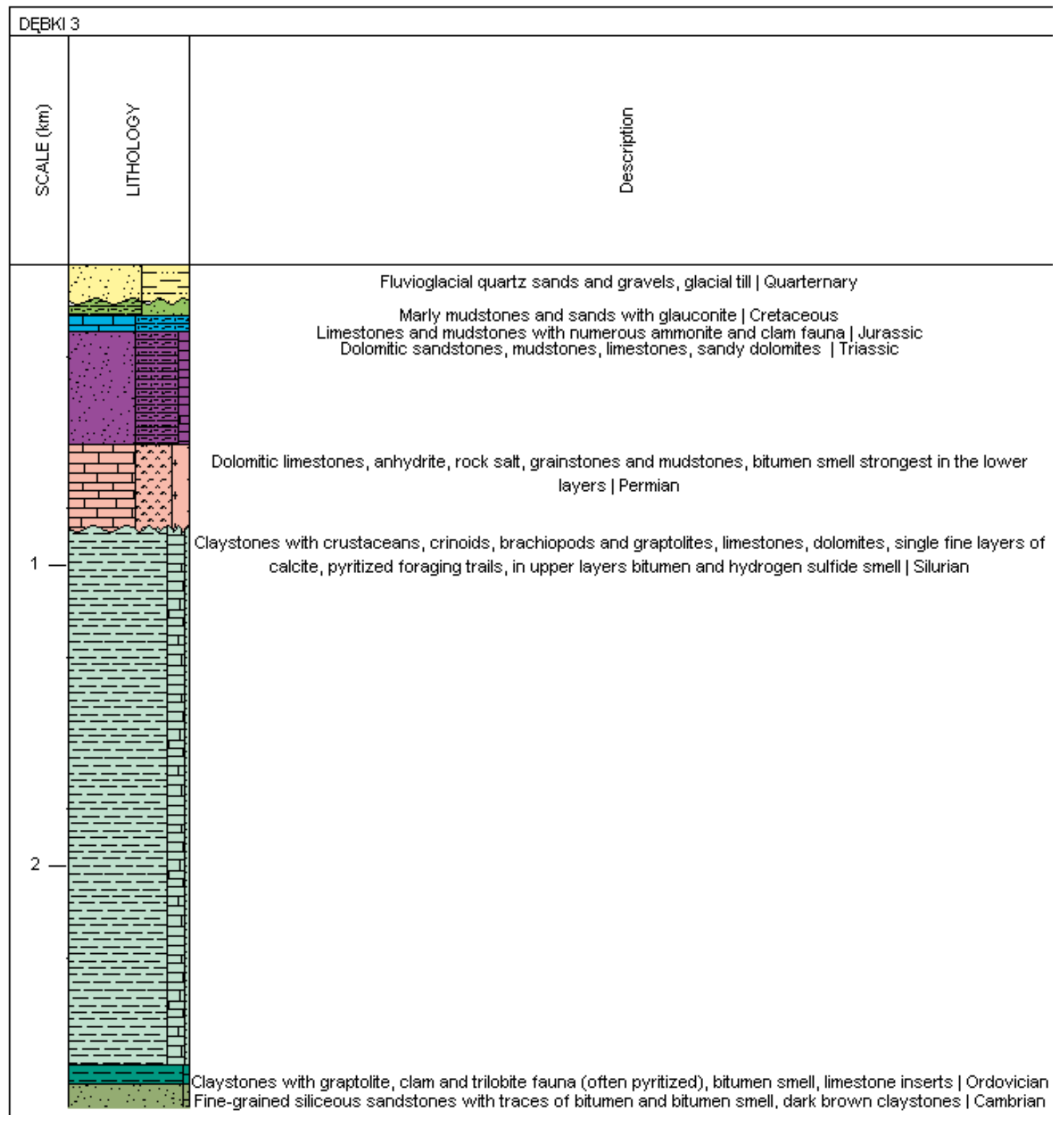

Fig. 5. Simplified profile of geological formations in Dębki (Pomeranian Voivodeship) chronostratigraphy and lithology.

\section{Summary and conclusions}

There are many boreholes in Northern Poland where hydrocarbons, rock salt or deep saline aquifers have been documented. Unfortunately, only less than $45 \%$ of them are really suitable for carrying out carbon dioxide injection processes. In the remaining ones, the geological traps considered are located too shallow, they do not have sufficient thickness or number of caverns and crevices. Repeatedly, insufficient sealing properties of considered structures also occurred.

In Northern Poland, individual cases of rock salt and brine levels were suitable for the CCS process. Nonetheless, the dominant group was definitely hydrocarbon deposits. The maximum thickness of described geological traps reaches about 300 meters. They can be analysed for $\mathrm{CO}_{2}$ injection and storage, but also enhanced oil and gas recovery to improve hydrocarbons extraction. There 
are also shale deposits, in which carbon dioxide can be used for dry fracturing. In some boreholes in the eastern part of the described area there were several different levels of geological formations in which the occurrence and possibility of hydrocarbon exploitation was documented. They have particular potential for perspectives of underground carbon dioxide storage.

Poland is facing a serious problem of reducing carbon dioxide emission. The CCS process seems to be one of its solutions. Northern Poland is perspective with regard to this issue. However, further research is needed to detail the safety, efficiency and profitability of underground carbon storage in geological traps in this area.

\section{References}

Asian Development Bank (2019) Carbon Dioxide-Enhanced Oil Recovery in Indonesia: An Assessment of its Role in a Carbon Capture and Storage Pathway. Manila, Philippines.

Akervoll I et al. (2009) Feasibility of Reproduction of Stored CO2 from the Utsira Formation at the Sleipner Gas Field. Energy Procedia 1(1):2557-2564. doi: 10.1016/j.egypro.2009.02.020

Bachu S, Dusseault M B (2005) Underground Injection of Carbon Dioxide in Salt Beds. Developments in Water Science 52: 637-648. https://doi.org/10.1016/S0167-5648(05)52049-5

Cała M, Cyran K (2018) Influence of the Anhydrite Interbeds on a Stability of the Storage Caverns in the Mechelinki Salt Deposit (Northern Poland). Archives of Mining Sciences 63(4): 1007-1025. DOI: $10.24425 / \mathrm{ams} .2018 .124990$

Carolus M. et al. (2017) Overview of a compre-hensive resource database for the assessment of recoverable hydrocarbons produced by carbon dioxide enhanced oil recovery. Techniques and Methods 7-C16: IX, 31 p. https://doi.org/10.3133/tm7C16

Central Geological Database CBDG (2020) Boreholes. Online: http://otworywiertnicze.pgi.gov.pl/

Czapowski G, Bukowski K (2010) Geology and resources of salt deposits in Poland: The state of the art. Geological Quarterly 54(4): 509-518

Czekański E et al. (2010) Hydrocarbon fields in the Zechstein Main Dolomite (Ca2) of the Gorzów Block (NW Poland). Przegląd Geologiczny 58: 695-703.

Elmabrouk S et al. (2017) An Overview of Power Plant CCS and CO2-EOR Projects. International Conference on Industrial Engineering and Operations Management, Rabat, Morocco, April 11-13, 2017

Eremin N, Nazarova L N (2001) Enhanced Oil Recovery Methods. Moscow: Gubkin Russian State University of Oil and Gas

Furre A K et al. (2017) 20 Years of Monitoring CO2-injection at Sleipner. Energy Procedia 114: 39163926. https://doi.org/10.1016/j.egypro.2017.03.1523

Gaurina-Međimurec, N., and Mavar, K., 2019. Carbon Capture and Storage (CCS): Geological Sequestration of CO2. In: $\mathrm{CO} 2$ Sequestration. Frazão, L. et al.(Ed.). DOI: 10.5772/intechopen.84428: 10.5772/intechopen.84428

Gavenas E. et al. (2015) CO2-emissions from Norvegian gas and oil extraction. Energy 90 (2): 19561966. https://doi.org/10.1016/j.energy.2015.07.025

Gorecki C, Sorensen J, Bremer J, Ayash S, Knudsen D, Holubnyak Y, Smith S, Steadman E, Harju J (2009) - Development of storage coefficients for carbon dioxide storage in deep saline formations. International Energy Agency, Paris

Irlam L (2017) Global costs of carbon capture and storage. 2017 Update. Global CCS Institute, Melbourne, Australia

Jarmołowicz-Szulc K (1998) Quartz cements in the Cambrian sandstones, Zarnowiec region, N Poland: A fluid inclusion study. Kwartalnik Geologiczny 42(3): 311-318

Jarzyna J et al. (2017) Shale Gas in Poland. In: Advances in Natural Gas Emerging Technologies, Al Megren, H., Altamimi, R. (Eds.) DOI: 10.5772/67301

Kosakowski P, Krajewski M (2015) Hydrocarbon potential of the Zechstein Main Dolomite (Upper Permian) in western Poland: Relation to organic matter and facies characteristics. Marine and Petroleum Geology, 68A: 675-694, https://doi.org/10.1016/j.marpetgeo.2015.03.026 
Kotarba M J, Lewan M D (2013) Sources of natural gases in Middle Cambrian reservoirs in Polish and Lithuanian Baltic Basin as determined by stable isotopes and hydrous pyrolysis of Lower Palaeozoic source rocks. Chemical Geology 345: 62-76. https://doi.org/10.1016/j.chemgeo.2013.02.023

Kotarba M J et al. (2003) Petroleum potential of Main Dolomite strata of the Kamień Pomorski area (northern Poland). Przeglad Geologiczny 51(7): 587-594

Kotarba M (2010) Origin of hydrocarbon gases accumulated in the Middle Cambrian reservoirs of the Polish part of the Baltic region. Geological Quarterly 54(2): 197-204.

Kvamme B, Aromada S A (2018) Alternative Routes to Hydrate Formation during Processing and Transport of Natural Gas with a Significant Amount of CO2: Sleipner Gas as a Case Study. J. Chem. Eng. 63(3): 832-844. https://doi.org/10.1021/acs.jced.7b00983

Labuda W (2014) Zastąpić wodę - nowe metody szczelinowania. online:

http://infolupki.pgi.gov.pl/pl/technologie/zastapic-wode-nowe-metody-szczelinowania

Lee K S et al. (2020) Numerical Modeling of CCS-EOR. In: CO2 Storage Coupled with Enhanced Oil Recovery, Lee, K.S. et al. (Eds.) pp.73-89. DOI: 10.1007/978-3-030-41901-1_4

Li X. et al. (2015) Hydraulic Fracturing in Shale with H2O, CO2 and N2. American Rock Mechanics Association, Article ID: ARMA-2015-786.

Loseth H (2019) Carbon Capture and Storage. Southeast Saskatchewan is currently home to two commercial CO2 enhanced oil recovery (EOR) project. Saskatchewan Ministry of Energy and Resources, Canada

Majorowicz J A (2004) Thermal lithosphere across the Trans-European Suture Zone in Poland. Geological Quarterly 48 (1): 1-14.

Maliński E et al. (2009) Biomarker features of sabkha-associated microbialites from the Zechstein Platy Dolomite (Upper Permian) of northern Poland. Palaeogeography Palaeoclimatology Palaeoecology 273(1-2): 92-101. DOI: 10.1016/j.palaeo.2008.12.005

Małkowski P et al. (2019) The effect of temperature on the mechanical properties and workability of rock salt. New Trends in Production Engineering 2(1): 384-393

Mamczur S et al. (1997) O największym złożu ropy naftowej w Polsce Barnówko-Mostno-Buszewo (BMB). Przegląd Geologiczny 45(6): 582-588.

Middleton R et al. (2014) CO2 as a fracturing fluid: Potential for commercial-scale shale gas production and CO2 sequestration. Energy Procedia 63: 7780-7784. DOI: 10.1016/j.egypro.2014.11.812

Müller K et al. (2014) Thermodynamic Constraints for the Utilization of $\mathrm{CO}_{2}$ Chemie Ingenieur Technik 86(4): 497-503. DOI: $10.1002 /$ cite.201300152

Nawrocki J, Becker A (ed.) (2017) Polish Geological Atlas. Polish Geological Institute- National Research Institute, Warsaw.

Nawrocki J, Poprawa P. (2006) Development of Trans-European Suture Zone in Poland: From Ediacarian rifting to Early Palaeozoic accretion. Geological Quarterly 50 (1): 59-76

Orlienok W W, Pęcherzewski K (2007) Of the Kaliningrad earthquakes tremors 21 September 2004. Słupskie Prace Geograficzne 3: 149-157.

Peryt T M (1986) The Zechstein (Upper Permian) Main Dolomite deposits of the Leba elevation, northern Poland: Facies and depositional history. Facies 14: 151-189

Peryt T M (2005) The Zechstein (upper permian) Main Dolomite deposits of the Leba elevation, northern Poland: Diagenesis. In: The Zechstein Facies in Europe. Conference Proceedings. Berlin: Springer.

Reguera D et al. (2013) Sediment quality assessments in carbon dioxide capture and storage in marine areas: an overview. UNISANTA BioScience 2(1) Invited paper. online: http://ojs.unisanta.br/index.php/bio/article/viewFile/149/227

Salim F et al. (2015) Design and Dynamic Simulation of a CO2 Injection System for CO2 Enhanced Oil Recovery. The 2015 World Congress on Advances in Civil, Environmental, and Materials Research (ACEM15), Incheon, Korea, August 25-29, 2015

Skupio R, Barberes G A (2017) Application of Gamma Spectrometry to Hydrocarbon Anomalies in Shale Cores at Pomerania Region, Poland. AAPG Annual Convention \& Exhibition, April 2-5, 2017, Houston, Texas.

Solomon S, Flach T (2010) Carbon dioxide (CO2) injection processes and technology. Developments and Innovation in Carbon Dioxide (CO2) Capture and Storage Technology 1: 435-466. https://doi.org/10.1533/9781845699574.4.435 
Klaudia Kusek

Speight J (2019) Natural Gas. A Basic Handbook. 2nd Edition. Elsevier. https://doi.org/10.1016/C2015-0-02190-6

Tarkowski R (2005) Geological sequestration of CO2. Publishing House of Institute of Mineral Resources and Energy of the Polish Academy of Sciences, Kraków

Tarkowski R (2017) Perspectives of using the geological subsurface for hydrogen storage in Poland. International Journal of Hydrogen Energy 42(1): 347-355

Tatarynowicz J (2001) Proecological solutions in petroleum (oil) and natural gas mining in the deposits of Barnówko - Mostno - Buszewo in the Polish Oil and Natural Gas Mining SA. Zeszyty Naukowe. Inżynieria Środowiska / Politechnika Zielonogórska 125: 335-343

Tatevossian R E et al. (2011) On the earthquakes in the Northern Baltic Shield in the spring of 1626. Natural Hazards 57(2): 133-150. DOI: 10.1007/s11069-010-9516-7.

Verma M K (2015) Fundamentals of Carbon Dioxide-Enhanced Oil Recovery (CO2-EOR) - A Supporting Document of the Assessment Methodology for Hydrocarbon Recovery Using CO2-EOR Associated with Carbon Sequestration. Open-File Report 2015-1071. U.S. Geological Survey, Reston, Virginia

Wang P T et al. (2020) Carbon capture and storage in China's power sector: Optimal planning under the $2{ }^{\circ} \mathrm{C}$ constraint. Applied Energy 263: 114694. https://doi.org/10.1016/j.apenergy.2020.114694

Watts R, Watts K (2015) Gas injection for shale gas recovery. Digital Refining. https://www.digitalrefining.com/article/1001073,Gas_injection_for_shale_gas_recovery.html

Wawrzyniak-Guz K (2019) Rock physics modelling for determination of effective elastic properties of the lower Paleozoic shale formation, North Poland. Acta Geophysica 67: 1967-1989. DOI: 10.1007/s11600-019-00355-6

Więcław D et al. (2010) Origin of oils accumulated in the Middle Cambrian reservoirs of the Polish part of the Baltic region. Geological Quarterly 54 (2): 205-216

Zhang Q et al. (2019) Numerical Simulations of Fracture Propagation in Jointed Shale Reservoirs under CO2 Fracturing. Geofluids, Article ID 2624716: 13 pp. https://doi.org/10.1155/2019/2624716

Zych I (2005) Paleogeography of the main dolomite structures in the polish Zechstein basin in aspect of hydrocarbon search. Technika Poszukiwań Geologicznych 44(3): 35-43 